\title{
The influence of socio-demographic and environmental factors on the fall rate in geriatric patients in primary health care
}

\author{
MAGDALENA SYLWIA KAMIŃSKA ${ }^{1, A-G}$, JACEK BRODOWSKI ${ }^{1, c, ~ D, ~}$, , BEATA KARAKIEWICZ ${ }^{2, ~ G}$ \\ ${ }^{1}$ Department of Primary Health Care, Pomeranian Medical University in Szczecin, Poland \\ 2 Public Health Department, Pomeranian Medical University in Szczecin, Poland
}

A - Study Design, B - Data Collection, C - Statistical Analysis, D - Data Interpretation, E - Manuscript Preparation, F - Literature Search, G - Funds Collection

\begin{abstract}
Summary Background. A fall is defined as an event which results in a person coming to rest inadvertently on the ground or floor or other lower level. Falls are the leading cause of injuries among geriatrics and a factor which significantly lowers their quality of life. Objectives. The aim of this study was to identify fall risk factors in the elderly with regard to their environmental situation and sociodemographic data.

Material and methods. This epidemiological population-based study involved 304 patients from selected outpatient clinics. The median age was 79 years. Our study employed a diagnostic survey-based method using an environmental inquiry of our devising, as well as the Tinetti Test (TT).

Results. A statistically significant correlation was found between the number of falls and such variables as age, the family structure and family care efficiency $(p<0.05)$. Gender did not affect the number of falls $(p>0.05)$. Regardless of whether the respondents experienced falls or not, a vast majority of them showed a need for information support concerning the reduction of fall risk in the future. Conclusions. 1. Risk factors for falls among geriatric patients include age, falls in the medical history, solitude as an adverse social situation and the unpreparedness of the family for taking non-professional care of their elderly relatives. 2. According to the respondents, information support may improve their knowledge of fall prevention and ways of handling the situation with increasingly limited self-reliance, and the preparation of their families for taking care of them may reduce the risk of falls. Key words: falls, primary health care, geriatrics.
\end{abstract}

Kamińska MS, Brodowski J, Karakiewicz B. The influence of socio-demographic and environmental factors on the fall rate in geriatric patients in primary health care. Fam Med Prim Care Rev 2017; 19(2): 139-143, doi: https://doi.org/10.5114/fmpcr.2017.67869.

\section{Background}

A fall is defined as an event which results in a person coming to rest inadvertently on the ground or floor or other lower level [1]. Falls are the leading cause of injuries among geriatrics and a factor which significantly lowers their quality of life $[2,3]$. Since they have serious medical, psychosocial and economic consequences, falls are counted among the so-called major geriatric problems. Therefore, fall prevention should be a priority for both seniors and their caregivers. According to literature, fall prevention should be implemented on four levels, namely health education, overall assessment of fall risk factors, reduction of community risk factors and individual rehabilitation programs [4, 5].

Falls are at present regarded as a crucial issue by representatives of various domains of science. The first studies on the occurrence and circumstances of falls in the geriatric population were carried out as early as in the 50 s and 60 s of the last century. They were either population research or were focused on specific groups of patients. The first attempts to develop research instruments for measuring the risk of falls took place at the end of the 1970s and the beginning of the 1980s [6]. The 1980s and 1990s saw many standardized questionnaires - still applied to this day - for gauging gait, balance and other factors potentially contributing to the risk of falls in the future with regard to overall geriatric assessment [7]. The subject of falls in the population of over 65-year-olds attracted the attention of Polish scientists at the beginning of the 1990s. As a review of world literature shows, at present, researchers are increasingly involved in selective, randomized-experimental and clinical-cohort studies $[8,9]$.

\section{Objectives}

The aim of this study was to identify fall risk factors in the elderly with regard to their environmental situation and sociodemographic data.

\section{Material and methods}

This epidemiological population-based study involved 304 patients aged 65-100 years from selected outpatient clinics. Women constituted $77.3 \%$ and men $22.7 \%$ of those analyzed (235 and 69, respectively). The median (Me) age was 79 years, and the quartile range (Q1-Q3) was 73-84 years. The key criteria for selecting participants were their availability at the moment of carrying out the study, no symptoms of exacerbation of concomitant diseases or other health problems, a mental state enabling the patients to cooperate with the researcher and understand her requests, the ability to move without assistance, as well as voluntary and deliberate agreement to participate in the study. All who met the criteria were included.

This survey-based study was conducted using an environmental inquiry of the authors' own design, employed to assess the socio-demographic, economic, socio-environmental and health situation of patients, as well as the circumstances of falls during the 12 months preceding the study. The inquiry had been developed on the basis of nursing documentation that is commonly used in primary health care centers.

The Tinetti Test (TT) was employed to evaluate patients' ability to walk and maintain balance. The TT enables the divi- 
sion of patients into three groups, depending on the level of their dependence and the risk of falls. The group at the highest risk obtains the lowest scores $(\leq 18)$. The group at moderate risk consists of people with scores of 19-23 points, and the group at the lowest risk is the one with scores of $\geq 24$ points.

Statistical analysis was performed using "Statistica $12 \mathrm{PL}$ (StatSoft Poland Inc.). The relationships between qualitative variables were assessed using a chi-square independence test. The significance of differences between quantitative variables was assessed using Spearman's rank correlation coefficient $\left(r_{s}\right)$. The character of the distribution of the quantitative variables was assessed using the Shapiro-Wilk test. The significance level was set at $p<0.05$. The study was approved by the Bioethical Commission of the Pomeranian Medical University in Szczecin (permission number KB-0080/141/09).

\section{Results}

The first stage of the research was an analysis of selected factors potentially contributing to falls. The study group included 233 (76.60\%) individuals who had experienced falls. Gender was not a significant contributor to falls in the elderly (test $\chi^{2}$; $p=0.111$ ). The authors scrutinized the relationship between gender and the number of falls, proving that gender had no influence on the number of falls (test $\chi^{2} ; p=0.231$ ). A statistical analysis of the results (Table 1 ) showed that the majority of both geriatric women and men had one fall on their scorecards (30.64\% vs. $34.78 \%)$. There were slightly more men than women who had not fallen at all ( $30.43 \%$ vs. $21.28 \%)$, and at the same time, there were fewer men than women who had experienced two falls $(15.94 \%$ vs. $21.70 \%)$ or more $(18.84 \%$ vs. $26.38 \%)$.

\begin{tabular}{|c|c|c|c|c|c|c|c|c|}
\hline \multirow{2}{*}{$\begin{array}{l}\text { Number } \\
\text { of falls }\end{array}$} & $n$ & $\%$ & $n$ & $\%$ & $n$ & $\%$ & \multirow{2}{*}{$\begin{array}{l}\text { Pear- } \\
\text { son's } \\
\chi^{2} \text { test }\end{array}$} & \multirow{2}{*}{$p$} \\
\hline & & & & & & & & \\
\hline 0 & 50 & 21.28 & 21 & 30.43 & 71 & 23.35 & \multirow{5}{*}{4.30} & \multirow{5}{*}{0.231} \\
\hline 1 & 72 & 30.64 & 24 & 34.78 & 96 & 31.58 & & \\
\hline 2 & 51 & 21.70 & 11 & 15.94 & 62 & 20.40 & & \\
\hline$\geq 3$ & 62 & 26.38 & 13 & 18.84 & 75 & 24.67 & & \\
\hline Total & 235 & 77.30 & 69 & 22.70 & \begin{tabular}{|l|}
304 \\
\end{tabular} & 100.00 & & \\
\hline
\end{tabular}

At the second stage of the study, the patients were divided into two groups with regard to age: group one consisted of subjects aged up to 79 years, and group two comprised those aged 80 years or over. The authors then analyzed the occurrence of falls in relation to age. This demonstrated that a majority of respondents had experienced falls regardless of their age $(78.73 \%$ of subjects aged 80 years or more vs. $74.85 \%$ of subjects aged up to 79 years). The results of the test for independence did not reveal a significant relationship between the age of the respondents (analyzed in two groups) and the occurrence of falls (test $\chi^{2} ; p=0.421$.

The authors also evaluated the relationship between the age group and the number of falls. The results obtained demonstrated that people aged up to 79 years experienced only one fall $(36.20 \%$ vs. $26.24 \%)$ or two falls $(22.09 \%$ vs. $18.44 \%)$ more often than their older counterparts. Three falls were significantly more often observed among older patients than those aged up to 79 years ( $34.75 \%$ vs. $15.95 \%)$. There was a statistically significant relationship between the age group and the number of falls (test $\chi^{2} ; p=0.002$ ) - older individuals fell considerably more frequently than younger ones (Table 2 ).

Statistical analysis revealed that falls happened to patients being at a high risk of falls according to the TT more often than to those with a low risk of falls $(87.60 \%$ and $69.34 \%$, respectiveIy). The relationship between the TT results and the occurrence of falls was statistically significant (test $\chi^{2} ; p=0.001$ ) (Table 3 ). It was also demonstrated that people with a lower risk of falls according to the TT experienced a lower number of falls $\left(r_{s}=\right.$ $-0.4 ; p=0.002$ ).

Table 2. Age group vs. the number of falls and the results of the test for independence between age group and the number of falls

\begin{tabular}{|c|c|c|c|c|c|c|c|c|}
\hline \multirow{2}{*}{$\begin{array}{l}\text { Number } \\
\text { of falls }\end{array}$} & \multicolumn{2}{|c|}{$\geq 80$ years } & \multicolumn{2}{|c|}{$65-79$ years } & \multicolumn{2}{|c|}{ Total } & \multirow{2}{*}{\begin{tabular}{|l|} 
Pear- \\
son's \\
$\chi^{2}$ test \\
\end{tabular}} & \multirow[t]{2}{*}{$p$} \\
\hline & $n$ & $\%$ & $n$ & $\%$ & $n$ & $\%$ & & \\
\hline 0 & 29 & \begin{tabular}{|l|}
20.57 \\
\end{tabular} & 42 & 25.77 & 71 & 23.35 & \multirow{5}{*}{14.57} & \multirow{5}{*}{0.002} \\
\hline 1 & 37 & \begin{tabular}{|l|}
26.24 \\
\end{tabular} & 59 & 36.20 & 96 & 31.58 & & \\
\hline 2 & 26 & 18.44 & 36 & 22.09 & 62 & 20.40 & & \\
\hline$\geq 3$ & 49 & 34.75 & 26 & 15.95 & 75 & 24.67 & & \\
\hline Total & 141 & \begin{tabular}{|l|}
46.38 \\
\end{tabular} & 163 & 53.62 & \begin{tabular}{|l|}
304 \\
\end{tabular} & 100.00 & & \\
\hline
\end{tabular}

Table 3. Results of the TT vs. the incidence of falls and the correlation between the number of falls and the results of the TT

\begin{tabular}{|c|c|c|c|c|c|c|c|c|}
\hline \multirow[t]{2}{*}{$\begin{array}{l}\text { Tinetti } \\
\text { test }\end{array}$} & \multicolumn{2}{|l|}{$\begin{array}{l}\text { Fall } \\
\text { Yes }\end{array}$} & \multicolumn{2}{|c|}{\begin{tabular}{|l} 
Fall \\
No
\end{tabular}} & \multicolumn{2}{|c|}{ Total } & \multirow{2}{*}{$\begin{array}{l}\text { Pear- } \\
\text { son's } \\
\chi^{2} \text { test }\end{array}$} & \multirow[t]{2}{*}{$p$} \\
\hline & $n$ & $\%$ & $n$ & $\%$ & $n$ & $\%$ & & \\
\hline $\begin{array}{l}\text { Highest } \\
\text { risk of } \\
\text { fall }\end{array}$ & 106 & 45.49 & 15 & 21.13 & 121 & 39.80 & \multirow{4}{*}{13.48} & \multirow{4}{*}{0.001} \\
\hline $\begin{array}{l}\text { Moder- } \\
\text { ate risk } \\
\text { of fall }\end{array}$ & 32 & 13.73 & 14 & 19.72 & 46 & 15.13 & & \\
\hline $\begin{array}{l}\text { Minimal } \\
\text { risk of } \\
\text { fall }\end{array}$ & 95 & 40.77 & 42 & 59.15 & 137 & 45.07 & & \\
\hline Total & 233 & 76.60 & 71 & 23.40 & 304 & 100.00 & & \\
\hline
\end{tabular}

Another aspect subjected to analysis was the relationship between family structure and the occurrence of falls. Most respondents lived alone, which referred both to those who had experienced a fall and those who had not ( $68.67 \%$ vs. $56.34 \%)$. The results of the test for independence did not reveal a significant relationship between the occurrence of falls and the family structure of the responds (test $\chi^{2} ; p=0.055$ ) (Table 4).

\begin{tabular}{|c|c|c|c|c|c|c|c|c|}
\hline \multirow[t]{2}{*}{$\begin{array}{l}\text { Family } \\
\text { structure }\end{array}$} & \multicolumn{2}{|l|}{\begin{tabular}{|l|} 
Fall \\
Yes \\
\end{tabular}} & \multicolumn{2}{|c|}{\begin{tabular}{|l|} 
Fall \\
No \\
\end{tabular}} & \multicolumn{2}{|c|}{ Total } & \multirow{2}{*}{$\begin{array}{l}\text { Pear- } \\
\text { son's } \\
\chi^{2} \text { test } \\
\end{array}$} & \multirow[t]{2}{*}{$p$} \\
\hline & $n$ & $\%$ & $n$ & $\%$ & $n$ & $\%$ & & \\
\hline Solitary & 160 & 68.67 & 40 & 56.34 & 200 & 65.78 & \multirow{3}{*}{3.67} & \multirow{3}{*}{0.055} \\
\hline Family & 73 & 31.33 & 31 & 43.66 & 104 & 34.22 & & \\
\hline Total & 233 & 76.60 & 71 & 23.40 & 304 & 100.00 & & \\
\hline
\end{tabular}

The authors then analyzed the relationship between family structure and the number of falls. As Table 5 shows, people living alone experienced two or three falls considerably more often than those living in a family $(22.50 \%$ and $30.00 \%$ vs. $16.35 \%$ and $14.42 \%)$. The latter group included significantly more individuals who had not fallen at all or had fallen only once $(29.81 \%$ and $39.42 \%$ vs. $20.00 \%$ and $27.50 \%$ ). The relationship between the family structure and the number of falls was statistically significant (test $\chi^{2} ; p=0.003$ ). Therefore, we can state that people living alone fell significantly more often than those living in a family.

The analysis demonstrated that a high risk of falls according to the TT was more common among people living alone than among their counterparts living with the families $(49.00 \%$ and $22.12 \%$, respectively). There was a statistically significant relationship between the structure of the family and the risk of falls according to the TT (test $\chi^{2} ; p=0.001$ ) (Table 6). 


\begin{tabular}{|c|c|c|c|c|c|c|c|c|}
\hline \multirow{2}{*}{$\begin{array}{l}\text { Number } \\
\text { of falls }\end{array}$} & $\bar{n}$ & $\%$ & $n$ & $\%$ & $n$ & $\%$ & \multirow{2}{*}{$\begin{array}{l}\text { Pear- } \\
\text { son's } \\
\chi^{2} \text { test }\end{array}$} & \multirow{2}{*}{$p$} \\
\hline & & & & & & & & \\
\hline 0 & 40 & 20.00 & 31 & 29.81 & 71 & 23.35 & \multirow{5}{*}{13.89} & \multirow{5}{*}{0.003} \\
\hline 1 & 55 & 27.50 & 41 & 39.42 & 96 & 31.58 & & \\
\hline 2 & 45 & 22.50 & 17 & 16.35 & 62 & 20.40 & & \\
\hline$\geq 3$ & 60 & 30.00 & 15 & 14.42 & 75 & 24.67 & & \\
\hline Total & 200 & 65.78 & 104 & 34.22 & 304 & 100.00 & & \\
\hline
\end{tabular}

\begin{tabular}{|c|c|c|c|c|c|c|c|c|}
\hline \multirow[t]{2}{*}{ Tinetti test } & \multicolumn{2}{|c|}{ Solitary } & \multicolumn{2}{|c|}{ Family } & \multicolumn{2}{|c|}{ Total } & \multirow{2}{*}{$\begin{array}{l}\text { Pear- } \\
\text { son's } \\
\chi^{2} \text { test } \\
\end{array}$} & \multirow[t]{2}{*}{$p$} \\
\hline & $n$ & $\%$ & $n$ & $\%$ & $n$ & $\%$ & & \\
\hline $\begin{array}{l}\text { Highest } \\
\text { risk of fall }\end{array}$ & 98 & 49.00 & 23 & 22.12 & 121 & 39.80 & \multirow{4}{*}{20.65} & \multirow{4}{*}{0.001} \\
\hline $\begin{array}{l}\text { Moderate } \\
\text { risk of fall } \\
\end{array}$ & 26 & 13.00 & 20 & 19.23 & 46 & 15.13 & & \\
\hline $\begin{array}{l}\text { Minimal } \\
\text { risk of fall }\end{array}$ & 76 & 38.00 & 61 & 58.65 & 137 & 45.07 & & \\
\hline Total & 200 & 65.78 & 104 & 34.22 & 304 & 100.00 & & \\
\hline
\end{tabular}

One more aspect of falls that the authors investigated was the ability of a family to take non-professional care of its elderly members. Evaluation of this ability was based on an analysis of various specific factors, such as: the structure, socio-economic situation, social functioning (professional work, school education) of the family, the physical and mental state of its members, their healthcare-related knowledge and skills and the emotional bonds between the family members. The statistical analysis demonstrated that the majority of both patients who had experienced a fall and those who had not regarded their families as unprepared to provide non-professional care $(63.09 \%$ vs. $59.15 \%)$. At the same time, it was observed that falls happened both to patients whose families had been prepared to undertake non-professional care and those whose relatives did not have the necessary skills (36.91\% vs. $63.09 \%)$. The outcomes of this study did not confirm a statistically significant relationship between the ability of the family to undertake non-professional care and the occurrence of falls (test $\chi^{2} ; p=0.549$ ) (Table 7). The majority of those surveyed experienced falls irrespective of whether their relatives were prepared to undertake non-professional care or not.

\begin{tabular}{|c|c|c|c|c|c|c|c|c|}
\hline \multirow[t]{2}{*}{$\begin{array}{l}\text { Prepara- } \\
\text { tion }\end{array}$} & \multicolumn{2}{|l|}{$\begin{array}{l}\text { Fall } \\
\text { Yes }\end{array}$} & \multicolumn{2}{|l|}{\begin{tabular}{|l} 
Fall \\
No \\
\end{tabular}} & \multicolumn{2}{|c|}{ Total } & \multirow{2}{*}{$\begin{array}{l}\text { Pear- } \\
\text { son's } \\
\chi^{2} \text { test }\end{array}$} & \multirow[t]{2}{*}{$p$} \\
\hline & $n$ & $\%$ & $n$ & $\%$ & $n$ & $\%$ & & \\
\hline Yes & 86 & 36.91 & 29 & 40.85 & 115 & 37.82 & \multirow[t]{3}{*}{0.35} & \multirow[t]{3}{*}{0.549} \\
\hline No & 147 & 63.09 & 42 & 59.15 & 189 & 62.17 & & \\
\hline Total & 233 & 76.60 & 71 & 23.40 & 304 & 100.00 & & \\
\hline
\end{tabular}

The authors further analyzed the relationship between the ability of a family to provide non-professional care and the number of falls. Patients whose relatives were prepared to undertake non-professional care reported only one fall more often than other respondents ( $41.74 \%$ vs. $25.40 \%$ ), and less often two $(19.13 \%$ vs. $21.16 \%)$ or three falls $(13.91 \%$ vs. $31.22 \%)$. There was a statistically significant relationship between the number of falls and the ability of a family to provide efficient care (test $\chi^{2} ; p=0.002$ ) (Table 8). Therefore, we can conclude that patients whose relatives were prepared to undertake non-professional care fell considerably less frequently.

\begin{tabular}{|c|c|c|c|c|c|c|c|c|}
\hline \multirow{2}{*}{$\begin{array}{l}\text { Number } \\
\text { of falls }\end{array}$} & \multicolumn{2}{|c|}{$\begin{array}{l}\text { Preparation } \\
\text { Yes } \\
\end{array}$} & \multicolumn{2}{|c|}{$\begin{array}{l}\text { Preparation } \\
\text { No }\end{array}$} & \multicolumn{2}{|l|}{ Total } & \multirow{2}{*}{$\begin{array}{l}\text { Pear- } \\
\text { son's } \\
\chi^{2} \text { test }\end{array}$} & \multirow{2}{*}{$p$} \\
\hline & 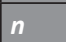 & $\%$ & $n$ & $\%$ & $n$ & $\%$ & & \\
\hline 0 & 29 & 25.22 & 42 & 22.22 & 71 & 23.35 & \multirow{5}{*}{15.14} & \multirow{5}{*}{0.002} \\
\hline 1 & 48 & 41.74 & 48 & 25.40 & 96 & 31.58 & & \\
\hline 2 & 22 & 19.13 & 40 & 21.16 & 62 & 20.40 & & \\
\hline$\geq 3$ & 16 & 13.91 & 59 & 31.22 & 75 & 24.67 & & \\
\hline Total & 200 & 65.78 & \begin{tabular}{|l|}
104 \\
\end{tabular} & 34.22 & 304 & 100.00 & & \\
\hline
\end{tabular}

Statistical calculations showed that the families of patients at a low risk of falls according to the TT were much more often ready to undertake non-professional care of their older relatives in the context of falls than the families of other patients $(50.36 \%$ and $49.64 \%$, respectively). This correlation was statistically significant (test $\chi^{2} ; p=0.0002$ ) (Table 9).

\begin{tabular}{|c|c|c|c|c|c|c|c|c|}
\hline \multirow[t]{2}{*}{$\begin{array}{l}\text { Tinetti } \\
\text { test }\end{array}$} & \multicolumn{2}{|c|}{$\begin{array}{l}\text { Preparation } \\
\text { Yes }\end{array}$} & \multicolumn{2}{|c|}{$\begin{array}{l}\text { Preparation } \\
\text { No }\end{array}$} & \multicolumn{2}{|c|}{ Total } & \multirow{2}{*}{$\begin{array}{l}\text { Pear- } \\
\text { son's } \\
\chi^{2} \\
\text { test }\end{array}$} & \multirow[t]{2}{*}{$p$} \\
\hline & $n$ & $\%$ & $n$ & $\%$ & $n$ & $\%$ & & \\
\hline $\begin{array}{l}\text { Highest } \\
\text { risk of fall }\end{array}$ & 29 & 23.97 & 92 & 76.03 & 121 & 39.80 & \multirow{4}{*}{19.05} & \multirow{4}{*}{0.0002} \\
\hline $\begin{array}{l}\text { Moderate } \\
\text { risk of fall }\end{array}$ & 17 & 36.96 & 29 & 63.04 & 46 & 15.13 & & \\
\hline $\begin{array}{l}\text { Minimal } \\
\text { risk of fall }\end{array}$ & 69 & 50.36 & 68 & 49.64 & 137 & 45.07 & & \\
\hline Total & 115 & 37.92 & 189 & 62.17 & 304 & 100.00 & & \\
\hline
\end{tabular}

The next stage of this study included an analysis of the relationship between the demand for information about fall prevention and the occurrence of falls. Regardless of whether those surveyed had experienced falls or not, the vast majority needed information on how to reduce the risk of falls in the future $(75.97 \%$ vs. $76.06 \%)$. There was no statistically significant relationship between the occurrence of falls and the demand for information support (test $\chi^{2} ; p=0.135$ ) (Table 10).

\begin{tabular}{|c|c|c|c|c|c|c|c|c|}
\hline \multirow{2}{*}{$\begin{array}{l}\text { Need for } \\
\text { infor- } \\
\text { mation } \\
\text { support }\end{array}$} & \multicolumn{2}{|l|}{\begin{tabular}{|l|} 
Fall \\
Yes
\end{tabular}} & \multicolumn{2}{|c|}{\begin{tabular}{|l|} 
Fall \\
No
\end{tabular}} & \multicolumn{2}{|c|}{ Total } & \multirow{2}{*}{$\begin{array}{l}\text { Pear- } \\
\text { son's } \\
\chi^{2} \text { test }\end{array}$} & \multirow[t]{2}{*}{$p$} \\
\hline & $n$ & $\%$ & $n$ & $\%$ & $n$ & $\%$ & & \\
\hline Yes & 177 & 75.97 & 54 & 76.06 & 231 & 75.98 & \multirow{4}{*}{4.01} & \multirow{4}{*}{0.135} \\
\hline No & 25 & 10.73 & 3 & 4.23 & 28 & 9.22 & & \\
\hline $\begin{array}{l}\text { Difficult } \\
\text { to say }\end{array}$ & 31 & 13.30 & 14 & 19.72 & 45 & 14.80 & & \\
\hline Total & 233 & 76.60 & 71 & 23.40 & 304 & 100.00 & & \\
\hline
\end{tabular}

Finally, the authors focused on the relationship between the need for information on fall prevention and the number of falls. Regardless of the number of falls, the vast majority of those surveyed were interested in obtaining information concerning ways of reducing the risk of falls in the future $(71.88 \%-80.00 \%)$. 


\begin{tabular}{|c|c|c|c|c|c|c|c|c|c|c|}
\hline \multirow[t]{2}{*}{ Number of falls } & \multicolumn{2}{|c|}{$\begin{array}{l}\text { Need for information } \\
\text { support } \\
\text { Yes }\end{array}$} & \multicolumn{2}{|c|}{$\begin{array}{l}\text { Need for information } \\
\text { support } \\
\text { No }\end{array}$} & \multicolumn{2}{|c|}{ Difficult to say } & \multicolumn{2}{|c|}{ Total } & \multirow[t]{2}{*}{$\begin{array}{l}\text { Pearson's } \\
\chi^{2} \text { test }\end{array}$} & \multirow[t]{2}{*}{$p$} \\
\hline & $n$ & $\%$ & $n$ & $\%$ & $n$ & $\%$ & $n$ & $\%$ & & \\
\hline 0 & 54 & 76.06 & 3 & 4.23 & 14 & \begin{tabular}{|l|}
19.72 \\
\end{tabular} & 71 & 23.35 & \multirow{5}{*}{17.7} & \multirow{5}{*}{0.007} \\
\hline 1 & 69 & 71.88 & 18 & 18.75 & 9 & 9.38 & 96 & 31.58 & & \\
\hline 2 & 48 & 77.42 & 3 & 4.84 & 11 & 17.74 & 62 & 20.40 & & \\
\hline$\geq 3$ & 60 & 80.00 & 4 & 5.33 & 11 & 14.67 & 75 & 24.67 & & \\
\hline Total & \begin{tabular}{|l|}
231 \\
\end{tabular} & 75.98 & \begin{tabular}{|l|}
28 \\
\end{tabular} & 9.21 & 45 & \begin{tabular}{|l|}
14.81 \\
\end{tabular} & 304 & 100.00 & & \\
\hline
\end{tabular}

\begin{tabular}{|c|c|c|c|c|c|c|c|c|c|c|}
\hline \multirow[t]{2}{*}{ Tinetti test } & \multicolumn{2}{|c|}{$\begin{array}{l}\text { Need for information support } \\
\text { Yes }\end{array}$} & \multicolumn{2}{|c|}{$\begin{array}{l}\text { Need for information support } \\
\text { No }\end{array}$} & \multicolumn{2}{|c|}{ Difficult to say } & \multicolumn{2}{|c|}{ Total } & \multirow[t]{2}{*}{$\begin{array}{l}\text { Pearson's } \\
\chi^{2} \text { test }\end{array}$} & \multirow[t]{2}{*}{$p$} \\
\hline & $n$ & $\%$ & $n$ & $\%$ & $n$ & $\%$ & $n$ & $\%$ & & \\
\hline Highest risk of fall & 97 & 41.99 & 11 & 39.29 & 13 & 28.89 & 121 & 39.80 & \multirow{4}{*}{3.00} & \multirow{4}{*}{0.406} \\
\hline Moderate risk of fall & 35 & 15.15 & 4 & 14.29 & 7 & 15.56 & 46 & 15.13 & & \\
\hline Minimal risk of fall & 99 & 42.86 & 13 & 46.43 & 25 & 55.56 & 137 & 45.07 & & \\
\hline Total & 231 & 75.98 & 28 & 9.22 & 45 & 14.80 & 304 & 100.00 & & \\
\hline
\end{tabular}

Such a need was considerably less common among patients who had fallen only once (18.75\%) than among others (4.23-5.33\%). A 'difficult to say' answer was given by $9.38 \%$ of respondents who had fallen only once and $19.72 \%$ of those who had not fallen at all (test $\chi^{2} ; p=0.007$ ) (Table 11).

The research results indicated that regardless of the risk of falls, most elderly people showed a need for information on how to reduce the risk of falls in the future. The results of statistical analysis showed a statistically significant association between the risk of falls according to the TT and the need for information on activities that may help avoid falls in the future (test $\chi^{2} ; p=0.406$ ) (Table 12).

In the opinion of $100 \%$ of the respondents, solid information support may improve the understanding of fall prevention issues and ways of handling the situation with increasingly limited self-reliance among geriatric patients. All respondents clearly stated that the preparation of the family for taking care of the patient may reduce the risk of falls.

Note: Some of the numbers in Tables 10 to 12 may suggest that the expected values required by the statistical test used in this study are too small (if the expected values are lower than 5 , the chi-square test can provide inaccurate results), which does not allow us to draw firm conclusions and suggests that further research is needed.

\section{Discussion}

The study described in this article did not demonstrate any relationship between gender and the occurrence of falls among seniors. On the other hand, Zhang et al. [10] and Gazibara et al. [11] reported that women fall more often than men, which was supported by Johansson et al. [12], who found that women are at a greater risk of falls than men.

The results obtained in this study suggest that age has no significant influence on the occurrence of falls among geriatrics. However, there is a statistically significant relationship between the age group and the number of falls. Older patients fall considerably more often than their younger counterparts and are at a higher risk of falling. This relationship has been fully confirmed by other authors. The studies of Yeh et al. [13] showed that advanced age is a predictor for multiple falls. Pluskiewicz et al. [14] suggested that the incidence of falls significantly increases with every decade of life. According to Zhang et al. [10], age and gender need to be taken into account when planning treatment for insomnia as a part of fall prevention for older adults.

According to the data obtained in this study, falls occur with the elderly regardless of whether their relatives are prepared to undertake non-professional care or not. Nevertheless, there is a statistically significant relationship between the number of falls and the efficiency of care provided by the family. What is more, families of patients at a low risk of falls were proven to be significantly more often prepared to undertake non-professional care. The relationship between the occurrence or the risk of falls and the ability of the family to provide efficient care has not been investigated to date. The care and nursing of a patient are considered to be one of the major functions of the family. There is a common belief that being a member of a family is sufficient to receive necessary assistance and support from its members. Even so, a number of factors and situations may result in the family's failure to provide care $[3,15]$. The ability of the family to offer efficient care is defined in terms of its structure and socio-economic situation, as well as the physical and mental state of its members, their healthcare-related knowledge and skills and the emotional bonds between family members $[3,15]$.

Obtaining information about a family and its ability to provide efficient care is a key element of health promotion and fall prevention proposed by district nurses. This is the starting point for deciding whether the family is ready to co-operate or whether it needs support and assistance from professional caregivers. In cases of the physical absence of those family members able to provide non-professional care, it helps to identify the patients' needs to be satisfied by social workers $[3,15]$.

Based on statistical analysis, it was found that, irrespective of the occurrence and the risk of falls, the vast majority of the respondents needed information on how to reduce the risk of falls in the future. It should be emphasized that those surveyed enquired about their previous falls and need for information support, showed interest in health-related issues and started to understand their role in health improvement. In the study of Stevens et al. [16], women were significantly more likely than men to report their falls, as well as to discuss falls and fall prevention, with a healthcare provider. The authors suggested that medical staff should consider asking all older patients about the history of falls, especially male patients, who are the least likely to seek medical attention.

The collecting of data concerning the demand for information about the ways of fall-risk reduction is an important part of the fall prevention and health promotion programs implemented by district nurses. This is the first step in selecting the objectives of health education, whose long-term goal is to develop healthy behaviors and attitudes, which assumes growing importance in the context of the threats posed by modern civilization. Therefore, an indirect purpose of these actions is to prepare patients of advanced age to take care of themselves, develop those skills necessary to enhance their health potential, avoid 
diseases or injuries typical in geriatrics and to introduce changes to their immediate environment in order to make them feel safe. Stahl and Albert [17] suggested that interventions to promote physical activity among fallers need to be gender-specific, as frequent falling among geriatrics is associated with a decline in common spare-time, household and walking activities.

\section{Conclusions}

1. Risk factors for falls among geriatric patients include age, falls in the medical history, solitude as an adverse social situation and the unpreparedness of the family for taking non--professional care of their elderly relatives.

2. According to the respondents, information support may improve their understanding of fall prevention issues and ways of handling the situation with increasingly limited self-reliance, and the preparation of their families for taking care of them may reduce the risk of falls.

3. District nurses need to develop educational skills that can be used during the implementation of prevention and safety promotion programs, thus contributing to a higher quality of life for older adults.

Source of funding: This work was funded by the Pomeranian Medical University in Szczecin.

Conflict of interest: The authors declare no conflict of interests.

\section{References}

1. WHO Global Report on Falls Prevention in Older Age. Geneva: World Health Organization; 2007.

2. Kamińska MS, Brodowski J, Karakiewicz B. Fall risk factors in community-dwelling elderly depending on their physical function, cognitive status and symptoms of depression. Int J Environ Res Public Health 2015; 12(4): 3406-3416.

3. Pytlak MA, Tomska N, Bohatyrewicz A, et al. Influence of selected demographic factors on traumas in persons over 65 years of age reporting to the Hospital Medical Ward. Fam Med Prim Care Rev 2016; 18(1): 49-53.

4. Kamińska MS. Rola pielęgniarki rodzinnej w prewencji upadków w grupie pacjentów w wieku geriatrycznym. Fam Med Prim Care Rev 2013; 15(1): 21-26 (in Polish).

5. Kamińska MS, Brodowski J, Karakiewicz B. The incidence of falls among geriatric outpatients in relation to the number and types of drugs taken. Fam Med Prim Care Rev 2016; 18(2): 123-127.

6. Tinetti ME. Performance-oriented assessment of mobility problems in elderly patients. J Am Geriatr Soc 1986; 34(2): 119-126.

7. Tinetti ME, Baker DI, Mc Vay G. A multifactorial intervention to reduce the risk of falling among elderly people living in the community. N Engl J Med 1994: 331(13): 821-827.

8. Cockayne S, Adamson J, Corbacho MB, et al. The REFORM study protocol: a cohort randomised controlled trial of a multifaceted podiatry intervention for the prevention of falls in older people. BMJ Open 2014; 4(12): e006977.

9. Kojima G, Masud T, Kendrick D, et al. Does the timed up and go test predict future falls among British community-dwelling older people? Prospective cohort study nested within a randomised controlled trial. BMC Geriatr 2015; 3(15): 38, doi: 10.1186/s12877-0150039.

10. Zhang Y, Cifuentes M, Gao X, et al. Age- and gender-specific associations between insomnia and falls in Boston Puerto Rican adults. Qual Life Res 2017; 26(1): 25-34.

11. Gazibara T, Kurtagic I, Kisic-Tepavcevic D, et al. Falls, risk factors and fear of falling among persons older than 65 years of age. Psychogeriatrics 2017 Jan 27, doi: 10.1111/psyg.12217 [Epub ahead of print].

12. Johansson J, Nordström A, Nordström P. Greater fall risk in elderly women than in men is associated with increased gait variability during multitasking. J Am Med Dir Assoc 2016; 17(6): 535-540.

13. Yeh $\mathrm{HF}$, Shao JH, Li CL, et al. Predictors of postoperative falls in the first and second postoperative years among elderly hip fracture patients. J Clin Nurs 2017 Jan 25, doi: 10.1111/jocn.13743 [Epub ahead of print].

14. Pluskiewicz W, Adamczyk P, Czekajło A, et al. Falls in RAC-OST-POL Study: epidemiological study in postmenopausal women aged over 55 years. Endokrynol Pol 2016; 67(2): 185-189.

15. Pluta A, Basińska-Drozd H, Faleńczyk K, et al. Udział pielęgniarki rodzinnej w opiece nad pacjentem geriatrycznym. Med Rodz 2014; 1 : 27-30 (in Polish).

16. Stevens JA, Ballesteros MF, Mack KA, et al. Gender differences in seeking care for falls in the aged Medicare population. Am J Prev Med 2012; 43(1): 59-62.

17. Stahl ST, Albert SM. Gender differences in physical activity patterns among older adults who fall. Prev Med 2015; 71: 94-100.

Tables: 12

Figures: 0

References: 17

Received: 07.11.2016

Revised: 31.01 .2017

Accepted: 12.02.2017

Address for correspondence:

Magdalena Sylwia Kamińska, MD, PhD

Zakład Podstawowej Opieki Zdrowotnej

Wydział Nauk o Zdrowiu PUM

ul. Żołnierska 48

71-210 Szczecin

Polska

Tel.: +48 91 48-00-973

E-mail:magdalena.kaminska@pum.edu.pl 